\title{
Synthesis of Carbon Nanotube Incorporated Metal Oxides for the Fabrication of Printable, Flexible Nickel-Zinc Batteries
}

\author{
Dr. Zhiqian Wang, Xianyang Meng, Kun Chen, and Prof. Somenath Mitra \\ Department of Chemistry and Environmental Science, New Jersey Institute of Technology, 161 \\ Warren Street, Newark, NJ 07102, USA
}

\begin{abstract}
The development of printable composite electrodes embedded with multiwalled carbon nanotubes (CNTs) for flexible nickel-zinc batteries is presented. The cathode and the anode comprised of $\mathrm{Ni}(\mathrm{OH})_{2}-\mathrm{CNT}$ and $\mathrm{ZnO}-\mathrm{CNT}$ respectively are prepared by coprecipitation of the metal oxides on CNTs. High loading ratio of electroactive materials increases the amount of active materials in electrode, but causes a lower material utilization efficiency due to decrease in overall electrode conductivity. The direct loading of active materials onto CNTs enhances contact where the CNTs serve the pathways for electron transport leading to higher performance than physical mixing of active ingredients. The cells show good performance even under bending conditions and the overall technology is scalable by printing methods.
\end{abstract}

\section{Keywords}

carbon nanotubes; flexible nickel-zinc batteries; nickel hydroxide; precipitations; zinc oxide

Flexible batteries are promising power sources for the next generation of electronics such as wearable sensors, implanted medical devices, bendable screens, and smart cards. ${ }^{[1-3]}$ The two most common designs for flexible batteries are the thin-film and cable batteries. ${ }^{[4-13]}$ In the former, the electrodes are painted or cast to form thin layers with a separator in between. ${ }^{[4,7,14,15]}$ This type of cells can be fabricated with commercially available printing techniques such as roll-to-roll printing and inkjet printing. Flexible batteries based on textiles or carbon cloths as matrix where the active materials are loaded/doped onto the scaffold have also been fabricated. ${ }^{[6,16,17]}$

Different flexible batteries have been studied and major efforts have gone into the development of both primary and secondary batteries including zinc-carbon, ${ }^{[7,8,13]}$ alkaline, ${ }^{[15,18-20]}$ zinc-air, ${ }^{[11,21]}$ nickel-iron, ${ }^{[22]}$ and lithium-ion systems. Primary flexible batteries that focus on low costs and toxicity have mostly used zinc as anode, with a metal oxide such as $\mathrm{MnO}_{2}$ as the active cathode material. Most of them have also used aqueous electrolytes, which are safer than the flammable organic electrolytes. However, rechargeable batteries are longer lasting, ecofriendly, and are often preferable to primary batteries. The most widely

Conflict of Interest

The authors declare no conflict of interest. 
studied is the lithium-ion battery using lithium metal oxides and carbon electrodes. [5,9,10,23-28]

Nickel-zinc batteries typically use $\mathrm{Ni}(\mathrm{OH})_{2}$ cathode, $\mathrm{Zn} / \mathrm{ZnO}$ anode, and an alkaline aqueous electrolyte. They show a higher output voltage of $1.6 \mathrm{~V}$ compared to Ni-MH cells that have an open-circuit voltage of 1.2 V. Besides, nickel-zinc batteries use aqueous electrolytes and are relatively safer. While flexible lithium batteries have been studied extensively, to the best of our knowledge there is only one published paper on a flexible nickel-zinc cell, ${ }^{[16]}$ where active materials were deposited on 3D hierarchical carbon cloth/ nanofiber substrates via atomic layer deposition of $\mathrm{ZnO}$ from $\mathrm{Zn}$ and water to form the anode, and immersion deposition of $\mathrm{NiO}$ from ammonia and nickel (II) sulfate to form the cathode. Other flexible substrates such as cotton textile, ${ }^{[29-32]}$ nylon, ${ }^{[33]}$ and polyester ${ }^{[34]}$ have also been used as substrates for flexible power sources. Here, the fabrics were soaked with solutions of active material for coating.

Highly electrically conductive, inert materials with high surface area are often important components of flexible electrode formulations. Promising materials include graphene, $[22,35-37] \mathrm{CNTs},{ }^{[26,38]}$ carbon microfiber, ${ }^{[6,39]}$ carbon black, ${ }^{[40]}$ porous materials from plant, $[41,42]$ and even organic conductive polymers. ${ }^{[43]}$ Each material has its own benefits and limitations. Porous carbons derived from plants tend to have high surface area as well as particle size. While reduced graphene oxides have good conductivity they tend to be less soluble. Both these are more suitable for supercapacitors and lithium-ion batteries. CNTs have been found to be excellent components of diverse electroactive composites. ${ }^{[36,38,44,45]}$ Similar to carbon fibers, the CNTs are highly conductive and can serve as the matrix or scaffolds for active materials. The 1D shape allows them to form a wide network within the matrix. Embedded in a composite, the CNTs serve as channels for electrons and electrolytes transport even with large amount of active materials loaded onto them. Such composites can be used to prepare electrode inks for flexible batteries. Thin-film techniques such as atomic layer deposition, ${ }^{[16]}$ chemical vapor deposition, ${ }^{[46]}$ and chemical approaches such as microwave-induced reactions ${ }^{[45,47]}$ have been used to load metal oxides on CNTs. Coprecipitation is a simple approach that can be effective in loading relatively large concentration of metal oxides on CNTs. Binders can be added to such formulations to provide the necessary cohesiveness, flexibility, and the ability to hold electrolytes for the electrodes. ${ }^{[8,15,20,21]}$ Such formulations can be converted into an ink and are amenable to mass production via techniques such as roll-to-roll printing.

The objective of this paper is to develop electrodes using CNT embedded metal oxides for flexible Ni-Zn batteries. Yet, another goal is to develop simple precipitative techniques to synthesize CNT-metal oxide composites that are suitable to form electrode inks that can be cast/printed directly onto flexible substrates to form electrode films.

The electrode inks, flexible electrodes, and the battery are shown in Figure 1. The flexible separator was placed between the electrodes.

Flexible $\mathrm{Ni}(\mathrm{OH})_{2}-\mathrm{CNT}$ cathode: $\mathrm{Ni}(\mathrm{OH})_{2}$ had poor electrical conductivity and hence conductive additives were needed to be added to the ink. $\mathrm{Ni}(\mathrm{OH})_{2}-\mathrm{CNT}$ composites were 
prepared through a reaction between $\mathrm{NaOH}$ and $\mathrm{Ni}\left(\mathrm{NO}_{3}\right)_{2}$. The CNT percentages in the composites were varied. The scanning electron microscopy (SEM), X-ray diffraction (XRD), thermal gravity analysis (TGA), and energy-dispersive X-ray spectroscopy (EDS) characterizations of the $\mathrm{Ni}(\mathrm{OH})_{2}$-CNT composites are shown in Figure 2. It could be seen from the SEM images that CNTs were embedded into the $\mathrm{Ni}(\mathrm{OH})_{2}$. Unless carboxylated, the CNTs tended to agglomerate. The EDS showed that the composite was mainly composed of nickel, carbon, and oxygen (Figure 2c). TGA of the $\mathrm{Ni}(\mathrm{OH})_{2}-\mathrm{CNT}$ composites (Figure 2d) was used to calculate the amount of CNTs and $\mathrm{Ni}(\mathrm{OH})_{2}$ in the composites. The $\mathrm{Ni}(\mathrm{OH})_{2}-$ CNT composites prepared here contained 40.8, 29.8, 24.0, and 18.7\% CNTs, respectively, which are referred to as $\mathrm{Ni}(\mathrm{OH})_{2}-\mathrm{CNT}_{40.8}, \mathrm{Ni}(\mathrm{OH})_{2}-\mathrm{CNT}_{29.8}, \mathrm{Ni}(\mathrm{OH})_{2}-\mathrm{CNT}_{24.0}$, and $\mathrm{Ni}(\mathrm{OH})_{2}-\mathrm{CNT}_{18.7}$. During TGA analysis, the decrease in weight between 200 and $230{ }^{\circ} \mathrm{C}$ was due to the decomposition of $\mathrm{Ni}(\mathrm{OH})_{2}$ to $\mathrm{NiO}$, while the decrease between 350 and $500{ }^{\circ} \mathrm{C}$ was attributed to the oxidation of CNTs to carbon dioxide. $\mathrm{Ni}(\mathrm{OH})_{2}$ exist mainly under two polymorphs, namely, $a$ and $\beta$. The $a-\mathrm{Ni}(\mathrm{OH})_{2}$ is relatively unstable and turns to $\beta$ in alkaline media, and $\beta$ turns into $\gamma$ upon overcharging. ${ }^{[48,49]} \mathrm{XRD}$ patterns of $\mathrm{Ni}(\mathrm{OH})_{2}{ }^{-}$ CNT did not show any obvious crystalline pattern although a couple of peaks were indexed at $33.34^{\circ}(100), 38.3^{\circ}(101)$, and $59.21^{\circ}$ (110) (ICCD Reference code 00-014-0117, ref. [48]). The sample was mostly amorphous (Figure 2e).

Cyclic voltammetry (Figure 2f) of $\mathrm{Ni}(\mathrm{OH})_{2}$-CNT showed an anodic peak at $0.35-0.4 \mathrm{~V}$ versus $\mathrm{Ag} / \mathrm{AgCl}$ electrode from the oxidation of nickel (II). Oxygen generation caused distortion of the curve and even covered the anodic peak at higher potential. This was particularly true at higher scan rates. The cathodic peaks at 0.15 and $0.05 \mathrm{~V}$ were attributed to the reduction of different nickel (III) forms to nickel (II), which was in line with what has been reported before. ${ }^{[50]}$

The different $\mathrm{Ni}(\mathrm{OH})_{2}$-CNT composites were used to fabricate nickel-zinc batteries in fixed Swagelok-type electrochemical cells described before. ${ }^{[8,15,20]}$ In each cycle, a cell was charged to $2 \mathrm{mAh}$ using constant current $(1 \mathrm{~mA})$-constant voltage $(1.9 \mathrm{~V})$, and then discharged under constant current of $0.8 \mathrm{~mA}$ until $1.1 \mathrm{~V}$. The cycling data of cells with different $\mathrm{Ni}(\mathrm{OH})_{2}-\mathrm{CNT}$ composites are shown in Figure 3. It also shows delivered cell capacity during each discharge as a function of cycle numbers.

Generally, as the amount of $\mathrm{Ni}(\mathrm{OH})_{2}$ increased (Figure $2 \mathrm{~b}$ ), the overall conductivity of composite and electrode decreased (Table 1), and so did the overall battery performance. High amount of CNTs caused cracking and disintegration of electrodes, leading to an increase in electrical resistance. It was found that the $\mathrm{Ni}(\mathrm{OH})_{2}-\mathrm{CNT}_{29.8}$ provided the optimum performance (Figure 3 and Table 1). Higher amount of CNTs (or lower loading of $\left.\mathrm{Ni}(\mathrm{OH})_{2}\right)$ in electrodes enhanced the electrode conductivity but would occupy the limited space in the battery, thus reducing the mass of electroactive materials. In general, the cell performance tended to increase as the amount of CNTs reached $29.8 \%$, beyond which the performance dropped. However, as seen from Table 1, a specific capacity based on active material and material utilization was the highest for the composite with $40.8 \%$ CNTs $\left(\mathrm{Ni}(\mathrm{OH})_{2}-\mathrm{CNT}_{40.8}\right)$. The material utilization reached $85 \%$ but lowered the total capacity because of the lower availability of $\mathrm{Ni}(\mathrm{OH})_{2}$. Loading a lower amount of $\mathrm{Ni}(\mathrm{OH})_{2}$ would further improve material utilization but at the cost of lowering the overall battery capacity. 
Flexible $\mathrm{ZnO}-\mathrm{CNT}$ anode: The $\mathrm{ZnO}$ in the anode was also loaded onto CNTs via coprecipitation to form a composite as shown in Figure 4. A reaction between $\mathrm{ZnCl}_{2}$ and $\mathrm{NaOH}$ was used to synthesize $\mathrm{Zn}(\mathrm{OH})_{2}$, which was then reduced to $\mathrm{ZnO}$ by heating at $200{ }^{\circ} \mathrm{C}$. The EDS results from the final composite showed the presence of $\mathrm{C}, \mathrm{Zn}$, and $\mathrm{O}$. The concentration of $\mathrm{ZnO}$ in the composite could be varied by varying the amount of the reactants during precipitation. When simply mixed together, flexible zinc anodes tended to crack at high CNT concentration and during bending. This has also been reported before. ${ }^{[15]}$ It was found that when CNTs were embedded into the $\mathrm{Zn}(\mathrm{OH})_{2} / \mathrm{ZnO}$ during precipitation such cracking was prevented. TGA results of $\mathrm{ZnO}-\mathrm{CNT}$ composites were used to calculate the amount of CNTs and $\mathrm{ZnO}$ in the composites. ZnO-CNT composites contained 31.9,

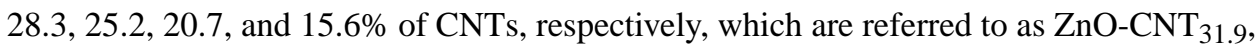

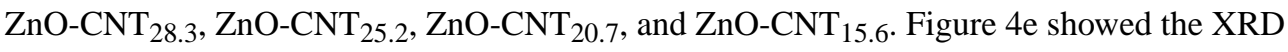
pattern of $\mathrm{ZnO}-\mathrm{CNT}$ sample, where peaks were indexed as $31.81^{\circ}(100), 34.45^{\circ}(002)$, $36.32^{\circ}(101), 47.62^{\circ}(102), 56.63^{\circ}(110), 62.86^{\circ}(103), 67.95^{\circ}(112)$, and $89.72^{\circ}(203)$, respectively, which corresponded to the characteristic hexagonal wurtzite structure of zinc oxide particles (Reference code 01-089-7102). Unlike the Ni-based cathode, the peaks in $\mathrm{ZnO}-\mathrm{CNT}$ showed crystal structure of zinc oxide.

Cyclic voltammetry analysis of $\mathrm{ZnO}-\mathrm{CNT}$ composites is shown in Figure 4g. Redox couple of $\mathrm{Zn} / \mathrm{ZnO}$ was observed between -1.35 and $-1.2 \mathrm{~V}$. Significant hydrogen evolution was observed at the lower potential end $(-1.35 \mathrm{~V})$. Because of the relatively high amount of CNTs in the composites, these metal oxide-CNT composites also showed capacitive behavior, especially in the case of ZnO-CNT.

These $\mathrm{ZnO}-\mathrm{CNT}$ composites were used to make anodes for nickel-zinc cells (Figures 5 and 6). A certain amount of metallic $\mathrm{Zn}$ was added to the electrode formulation to enhance conductivity and discharge performance. Since the anode now was the limiting reagent, a different charge-discharge cycle was used for evaluation. For the first two cycles the cell was charged to $4 \mathrm{mAh}$ using constant current $(4 \mathrm{~mA})$-constant voltage (1.9 V) method, and then discharged under constant current of $4 \mathrm{~mA}$ until discharged to $1.4 \mathrm{~V}$ for electrode activation. From the third cycle, a typical cell was charged to $4 \mathrm{mAh}$ using constant current $(2 \mathrm{~mA})$-constant voltage $(1.9 \mathrm{~V})$ method, and then discharged under constant current of 1.6 $\mathrm{mA}$ till 1.2 V. Figure 5 shows data comparing cells made with the $\mathrm{ZnO}^{-\mathrm{CNT}_{15.6}}$ composite (a total of $10 \%$ CNTs in electrode) and commercial ZnO (4\% CNT in electrode). The ZnOCNT composite showed better performance, which could be attributed to higher CNT amount. A 10\% CNT electrode was also prepared by physical mixing of ingredients, however it cracked and materials peeled off upon bending.

Composites with different CNT percentages were tested (Figure 6a). The anode ink contained $64 \%$ of the $\mathrm{ZnO}-\mathrm{CNT}$ composite and $22 \%$ of zinc metal and rest were binders and additives (all weights expressed on a dry basis). Low amount of CNTs led to high electrode

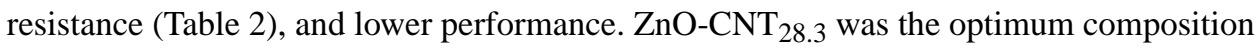

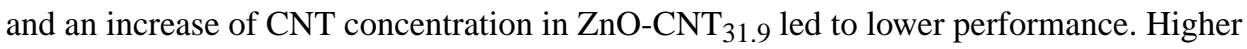
CNT concentrations increased the viscosity of the paints, while decreasing flexibility and leading to cracks formation. Hence, the amount of CNTs in the composite is an important consideration. 
Morphology of CNTs has impact on properties like dispersibility. Among these, surface functional groups tend have a more significant impact than length or diameter. ${ }^{[51]}$ We have reported that the treatment of CNTs before using them as electrode ingredients could alter the physical and electrochemical properties. ${ }^{[20,52,53]}$ Based on these data, the CNTs were functionalized for $10 \mathrm{~min}$ (FCNT-10) and $40 \mathrm{~min}$ (FCNT-40), respectively. The resulted carboxylated CNTs containing different levels of carboxylation (Table 3) were tested as an alternate to raw $\mathrm{CNTs}$ to form an equivalent $\mathrm{ZnO}-\mathrm{CNT}_{28.3}$ composite with two different levels of carboxylation. It could be seen from Figure 6 that the carboxylated CNTs showed lower performance that decreased with the degree of carboxylation. Results were similar when CNT-Ni $(\mathrm{OH})_{2}$ composites were synthesized with carboxylated CNTs and the data were not presented here for brevity.

In an effort to enhance anode performance, $\mathrm{Ca}(\mathrm{OH})_{2}$ was added as an additive where calcium zincate served as a rechargeable anode material, which has been known to reduce dendrite and morphology changes associated with pure $\mathrm{Zn}-\mathrm{ZnO}$ anode. ${ }^{[54-56]}$ Anodes containing $14 \%$ of $\mathrm{Ca}(\mathrm{OH})_{2}$ were prepared and tested, however these electrodes showed lower performance (Figure 7). Zn metal, which could improve both conductivity and

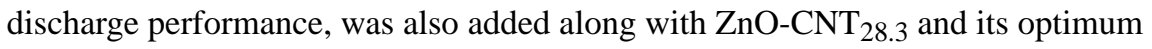
concentration was determined. Three concentrations, namely, 20, 30, and $38 \%$ of $\mathrm{Zn}$ in the ink formulation were tested, and $30 \%$ showed the best performance.

Flexible cells: In the fabrication of flexible cells, the evolution of hydrogen gas appeared to pose a problem. This was also expected from the cyclic voltammogram. This was greatly inhibited when the steel current collector was coated with materials with higher overpotential such as Zn (Figure 8). ${ }^{[57]}$ Two flexible cells were connected in series to power LED lights as shown in Figure 1d. The specific capacity of the flexible cell was $42 \mathrm{mAh} \mathrm{g}^{-1}$, which could be significantly enhanced by improving the packaging. The performance of the flexible cell under bending conditions is shown in Figure 8. Cells were attached to cylinder substrate with certain radii and then tested. During bending, parts of the electrodes and separator can stack together and enhance contact in some sections while other parts may separate to lose contact. In the cells fabricated here, no drop in performance was observed under bending conditions in terms of capacity or voltage. Cycle numbers could also be significantly improved by advanced packaging methods.

In summary, printable ink formulations for flexible electrodes were developed by synthesizing metal oxide-CNT composites, which were used to fabricate flexible Ni-Zn batteries. With the increase in CNT incorporation into the active materials, the composites showed relatively higher electrical conductivity. CNT carboxylation improved dispersion but did not show performance enhancement. The resulting electrode inks were suitable for conventional printing methods such as screenprinting, and there was flexibility as far as loading of electroactive materials and additives was concerned.

\section{Experimental Section}

The $\mathrm{Ni}(\mathrm{OH})_{2}-\mathrm{CNT}$ composites were prepared by stoichiometric reaction between prepared 2 $\mathrm{m} \mathrm{NaOH}$ (Sigma Aldrich, 97\%) solution and $0.194 \mathrm{~m} \mathrm{Ni}\left(\mathrm{NO}_{3}\right)_{2}$ (Sigma Aldrich, 
hexahydrate, 99\%), in presence of multiwalled CNTs (purity 95\%, diameter 20-30 nm, length 10-30 $\mu \mathrm{m}$, Cheap Tubes Inc. Brattleboro, VT). The purification and functionalization of CNTs were performed in a Microwave Accelerated Reaction System (Mode: CEM Mars) using experimental procedures previously reported. ${ }^{[52]} \mathrm{CNTs}$ were dispersed in $\mathrm{Ni}\left(\mathrm{NO}_{3}\right)_{2}$, stirred and sonicated (Omni Sonic Ruptor 250) for $30 \mathrm{~min}$ each, before $2 \mathrm{~m} \mathrm{NaOH}$ was added at the rate of $0.8 \mathrm{~mL} \mathrm{~min}{ }^{-1}$. Resulted samples were filtrated and dried at $90{ }^{\circ} \mathrm{C}$ under vacuum for $12 \mathrm{~h}$. Typical cathode slurry was prepared by adding $90 \% \mathrm{Ni}(\mathrm{OH})_{2}-\mathrm{CNT}$ composite and $10 \%$ polyethylene oxide (PEO, Sigma Aldrich, $M_{\mathrm{V}} \approx 400000$ ) binder, into deionized (DI) water. $0.05 \mathrm{~g}$ of such electrode slurry was also pasted onto $12 \mathrm{~m} \times 10 \mathrm{~mm}$ polyethylene terephthalate (PET) film to measure the electrical resistance between the distances of $12 \mathrm{~mm}$. After mixing the components in DI water, the paste was sonicated for $30 \mathrm{~min}$, and then stirred for $20 \mathrm{~h}$ to form a homogeneous slurry. During cathode optimization, the anode was made with $4 \%$ PEO binder, $4 \%$ CNTs, $1 \%$ methylcellulose (Sigma Aldrich, $M_{\mathrm{n}} \approx 40000$ ), $2 \%$ bismuth (III) oxide (Sigma Aldrich, 90-210 nm particle size, $299.8 \%$ ), 35\% zinc oxide (Sigma Aldrich, $299 \%$ ), and 54\% zinc powder (Sigma Aldrich, $₫ 10 \mu \mathrm{m}, \geq 98 \%)$. The anode was stoichiometrically in excess.

Similar to cathode $\mathrm{Ni}(\mathrm{OH})_{2}-\mathrm{CNT}$ composite, anode $\mathrm{ZnO}-\mathrm{CNT}$ composites were also prepared from stoichiometric coprecipitation method, with $82.25 \mathrm{~g} \mathrm{~L}^{-1}$ zinc chloride (Sigma Aldrich, $298 \%$ ) aqueous solution added into $2 \mathrm{~m} \mathrm{NaOH}$ solutions at the rate of $0.4 \mathrm{~mL}$ min ${ }^{-1}$ in presence of CNTs. Resulted samples were filtrated and dried at $200{ }^{\circ} \mathrm{C}$ under vacuum for $12 \mathrm{~h}$ to get the $\mathrm{ZnO}-\mathrm{CNT}$ composites. Equal amounts $(0.05 \mathrm{~g})$ of $\mathrm{ZnO}-\mathrm{CNT}$ composite slurries containing $10 \%$ PEO were painted onto PET films and dried like $\mathrm{Ni}(\mathrm{OH})_{2}-\mathrm{CNT}$, before electrical resistance was measured between the distances of $2 \mathrm{~mm}$. The battery anode paste contained zinc powder, PEO binder, methyl cellulose, and bismuth (III) oxide. In some of the formulations, zinc oxide, calcium hydroxide (Sigma Aldrich, $\geq 95$ ), and CNTs were also included. The powders were mixed with DI water and then stirred to form a homogeneous anode paste. Attempts were made to optimize the amount of zinc, zinc oxide, $\mathrm{ZnO}-\mathrm{CNT}$ composites, and $\mathrm{Ca}(\mathrm{OH})_{2}$. During anode optimization, cathode was typically fixed with $10 \%$ binder and $90 \% \mathrm{Ni}(\mathrm{OH})_{2}-\mathrm{CNT}_{2.353}$ composite, which was also abundant.

Swagelok-type cells using graphite rod current collectors and glass fiber separator (Grade GF/A: $1.6 \mu \mathrm{m}$, Whatman) were assembled to optimize the electrode formulation. ${ }^{[15]}$ The electrolyte was $8.5 \mathrm{~m} \mathrm{KOH}$ solution saturated by $\mathrm{ZnO}$, and contained $0.5 \mathrm{~m}$ sodium tetraborate (decahydrate, $\geq 99.8 \%$ ). For flexible cells, electrodes were prepared by casting the electrode slurry onto the stainless steel 316 current collector on the adhesive side of PET film coated with ethylene vinyl acetate (EVA) resin. The typical electrode area was $3 \times 2$ $\mathrm{cm}$. In some flexible cells, current collectors for anode were electroplated with thin layer of zinc. After applying the slurries onto the current collectors, the electrodes were allowed to dry under room temperature for $4 \mathrm{~h}$. The last 5 minutes of drying was under vacuum (9.893 $\mathrm{kPa}$ ). The typical weights of the cathode and anode after drying were 0.038 and $0.064 \mathrm{~g}$, respectively. The battery was thermally sealed with a glass fiber separator and a PTFE separator $(5.0 \mu \mathrm{m}$, ANOW) sandwiched between electrodes. Flexible electrodes after drying are shown in Figure 1. 
SEM with EDS were collected on a LEO 1530 VP scanning electron microscope. TGA was done on PerkinElmer Pyris 1. XRD patterns were taken on a PANalytical Empyrean XRD. During the $\mathrm{CV}$ ) analysis, the working electrodes contained $90 \% \mathrm{Ni}(\mathrm{OH})_{2}-\mathrm{CNT}$ and $80 \%$ ZnO-CNT, respectively, with the rest being PEO. CV was carried out on a Homiangz 320C electrochemical analyzer versus a standard $\mathrm{Ag}-\mathrm{AgCl}$ electrode in $8.5 \mathrm{~m} \mathrm{KOH}$ electrolyte. The electrochemical performance of the cells was measured using a MTI Battery Analyzer (Richmond, CA). The Ni-Zn cells were charged using constant current-constant voltage method and discharged under constant current. The flexible batteries were firmly attached to solid cylinder substrates of certain radii and tested to examine electrochemical performance under bending conditions.

\section{Acknowledgements}

This work was funded by a grant from the National Institute of Environmental Health Sciences (NIEHS) under Grant No. R01ES023209. Any opinions, findings, and conclusions or recommendations expressed in this material are those of the author(s) and do not necessarily reflect the views of the NIEHS.

\section{References}

[1]. Hahn R, Reichl H, presented at Wearable Computers, 1999, Digest of Papers, the Third Int. Symp., San Francisco, CA, USA Oct. 1999.

[2]. Siegel AC, Phillips ST, Dickey MD, Lu N, Suo Z, Whitesides GM, Adv. Funct. Mater 2010, 20, 28.

[3]. Coleman JP, Lynch AT, Madhukar P, Wagenknecht JH, Sol. Energy Mater. Sol. Cells 1999, 56, 395.

[4]. Dennler G, Bereznev S, Fichou D, Holl K, Ilic D, Koeppe R, Krebs M, Labouret A, Lungenschmied C, Marchenko A, Meissner D, Mellikov E, Méot J, Meyer A, Meyer T, Neugebauer H, Öpik A, Sariciftci NS, Taillemite S, Wöhrle T, Sol. Energy 2007, 81, 947.

[5]. Gaikwad AM, Khau BV, Davies G, Hertzberg B, Steingart DA, Arias AC, Adv. Energy Mater 2015, 5, 1401389.

[6]. Guan C, Zhao W, Hu Y, Ke Q, Li X, Zhang H, Wang J, Adv. Energy Mater 2016, 6, 1601034.

[7]. Hiralal P, Imaizumi S, Unalan HE, Matsumoto H, Minagawa M, Rouvala M, Tanioka A, Amaratunga GAJ, ACS Nano 2010, 4, 2730. [PubMed: 20415426]

[8]. Wang Z, Bramnik N, Roy S, Di Benedetto G, Zunino Iii JL, Mitra S, J. Power Sources 2013, 237 , 210.

[9]. Kwon YH, Woo S-W, Jung H-R, Yu HK, Kim K, Oh BH, Ahn S, Lee S-Y, Song S-W, Cho J, Shin H-C, Kim JY, Adv. Mater 2012, 24, 5192. [PubMed: 22886776]

[10]. Lee S-Y, Choi K-H, Choi W-S, Kwon YH, Jung H-R, Shin H-C, Kim JY, Energy Environ. Sci 2013, 6, 2414.

[11]. Park J, Park M, Nam G, Lee J-S, Cho J, Adv. Mater 2015, 27, 1396. [PubMed: 25532853]

[12]. Yousaf M, Shi HTH, Wang Y, Chen Y, Ma Z, Cao A, Naguib HE, Han RPS, Adv. Energy Mater 2016, 6, 1600490.

[13]. Yu X, Fu Y, Cai X, Kafafy H, Wu H, Peng M, Hou S, Lv Z, Ye S, Zou D, Nano Energy 2013, 2, 1242.

[14]. Gaikwad AM, Steingart DA, Ng TN, Schwartz DE, Whiting GL, Appl. Phys. Lett 2013, 102, 233302.

[15]. Wang Z, Wu Z, Bramnik N, Mitra S, Adv. Mater 2014, 26, 970. [PubMed: 24510667]

[16]. Liu J, Guan C, Zhou C, Fan Z, Ke Q, Zhang G, Liu C, Wang J, Adv. Mater 2016, 28, 8732. [PubMed: 27562134]

[17]. Lee Y-H, Kim J-S, Noh J, Lee I, Kim HJ, Choi S, Seo J, Jeon S, Kim T-S, Lee J-Y, Choi JW, Nano Lett. 2013, 13, 5753. [PubMed: 24164580] 
[18]. Gaikwad AM, Whiting GL, Steingart DA, Arias AC, Adv. Mater 2011, 23, 3251. [PubMed: 21661062]

[19]. Ghaemi M, Amrollahi R, Ataherian F, Kassaee MZ, J. Power Sources 2003, 117, 233.

[20]. Wang Z, Mitra S, J. Power Sources 2014, 266, 296.

[21]. Wang Z, Meng X, Wu Z, Mitra S, J. Energy Chem 2017, 26, 129.

[22]. Liu J, Chen M, Zhang L, Jiang J, Yan J, Huang Y, Lin J, Fan HJ, Shen ZX, Nano Lett. 2014, 14, 7180 [PubMed: 25402965]

[23]. Hamid NA, Wennig S, Hardt S, Heinzel A, Schulz C, Wiggers H, J. Power Sources 2012, 216, 76.

[24]. Ihlefeld JF, Clem PG, Doyle BL, Kotula PG, Fenton KR, Apblett CA, Adv. Mater 2011, 23, 5663. [PubMed: 22057430]

[25]. Jia X, Yan C, Chen Z, Wang R, Zhang Q, Guo L, Wei F, Lu Y, Chem. Commun 2011, 47, 9669.

[26]. Noerochim L, Wang J-Z, Chou S-L, Wexler D, Liu H-K, Carbon 2012, 50, 1289.

[27]. Ren HM, Ding YH, Chang FH, He X, Feng JQ, Wang CF, Jiang Y, Zhang P, Appl. Surf. Sci 2012, 263, 54.

[28]. Saunier J, Alloin F, Sanchez JY, Caillon G, J. Power Sources 2003, 119, 454.

[29]. Gao Z, Song N, Zhang Y, Li X, Nano Lett. 2015, 15, 8194. [PubMed: 26588035]

[30]. Gao Z, Zhang Y, Song N, Li X, Electrochim. Acta 2017, 246, 507.

[31]. Gao Z, Song N, Zhang Y, Li X, RSC Adv. 2015, 5, 15438.

[32]. Gao Z, Bumgardner C, Song N, Zhang Y, Li J, Li X, Nat. Commun 2016, 7, 11586. [PubMed: 27189776]

[33]. Gaikwad AM, Zamarayeva AM, Rousseau J, Chu H, Derin I, Steingart DA, Adv. Mater 2012, 24, 5071. [PubMed: 22760812]

[34]. Pu X, Li L, Song H, Du C, Zhao Z, Jiang C, Cao G, Hu W, Wang ZL, Adv. Mater 2015, 27, 2472. [PubMed: 25736078]

[35]. Gao Z, Song N, Li X, J. Mater. Chem. A 2015, 3, 14833.

[36]. Zhi M, Xiang C, Li J, Li M, Wu N, Nanoscale 2013, 5, 72. [PubMed: 23151936]

[37]. Gao Z, Yang W, Wang J, Song N, Li X, Nano Energy 2015, 13, 306.

[38]. Chen P, Chen H, Qiu J, Zhou C, Nano Res. 2010, 3, 594.

[39]. Bao L, Zang J, Li X, Nano Lett. 2011, 11, 1215. [PubMed: 21306113]

[40]. Lau XC, Wang Z, Mitra S, Sol. Energy Mater. Sol. Cells 2014, 128, 69.

[41]. Zhang Y, Gao Z, Song N, Li X, Electrochim. Acta 2016, 222, 1257.

[42]. Biswal M, Banerjee A, Deo M, Ogale S, Energy Environ. Sci, 2013, 6, 1249.

[43]. Zang J, Li X, J. Mater. Chem 2011, 21, 10965.

[44]. Kang YJ, Kim B, Chung H, Kim W, Synth. Met 2010, 160, 2510.

[45]. Yan J, Fan Z, Wei T, Cheng J, Shao B, Wang K, Song L, Zhang M, J. Power Sources 2009, 194, 1202.

[46]. Arod P, Shivashankar SA, RSC Adv. 2015, 5, 59463.

[47]. Jingyi B, Zhude X, Yifan Z, Chem. Lett 2006, 35, 96.

[48]. Delahaye-Vidal A, Beaudoin B, Sac-Epée N, Tekaia-Elhsissen K, Audemer A, Figlarz M, Solid State Ionics 1996, 84, 239.

[49]. Van der Ven A, Morgan D, Meng YS, Ceder G, J. Electrochem. Soc 2006, 153, A210.

[50]. Pissinis DE, Sereno L. n. E., Marioli JM, Open J. Phys. Chem 2012, 2, 11.

[51]. Hamilton RF, Wu Z, Mitra S, Shaw PK, Holian A, Part. Fibre Toxicol 2013, 10, 57. [PubMed: 24225053]

[52]. Wang Z, Wu Z, Di Benedetto G, Zunino III JL, Mitra S, Carbon 2015, 91, 103.

[53]. Wu Z, Wang Z, Yu F, Thakkar M, Mitra S, J. Nanopart. Res 2017, 19, 16. [PubMed: 29046611]

[54]. Yu J, Yang H, Ai X, Zhu X, J. Power Sources 2001, 103, 93.

[55]. Takamura T, Shirogami T, Niki H, Aizawa K, Google Patents, 1977.

[56]. Gagnon EG, Wang YM, J. Electrochem. Soc 1987, 134, 2091. 
[57]. Lee TS, J. Electrochem. Soc 1971, 118, 1278. 

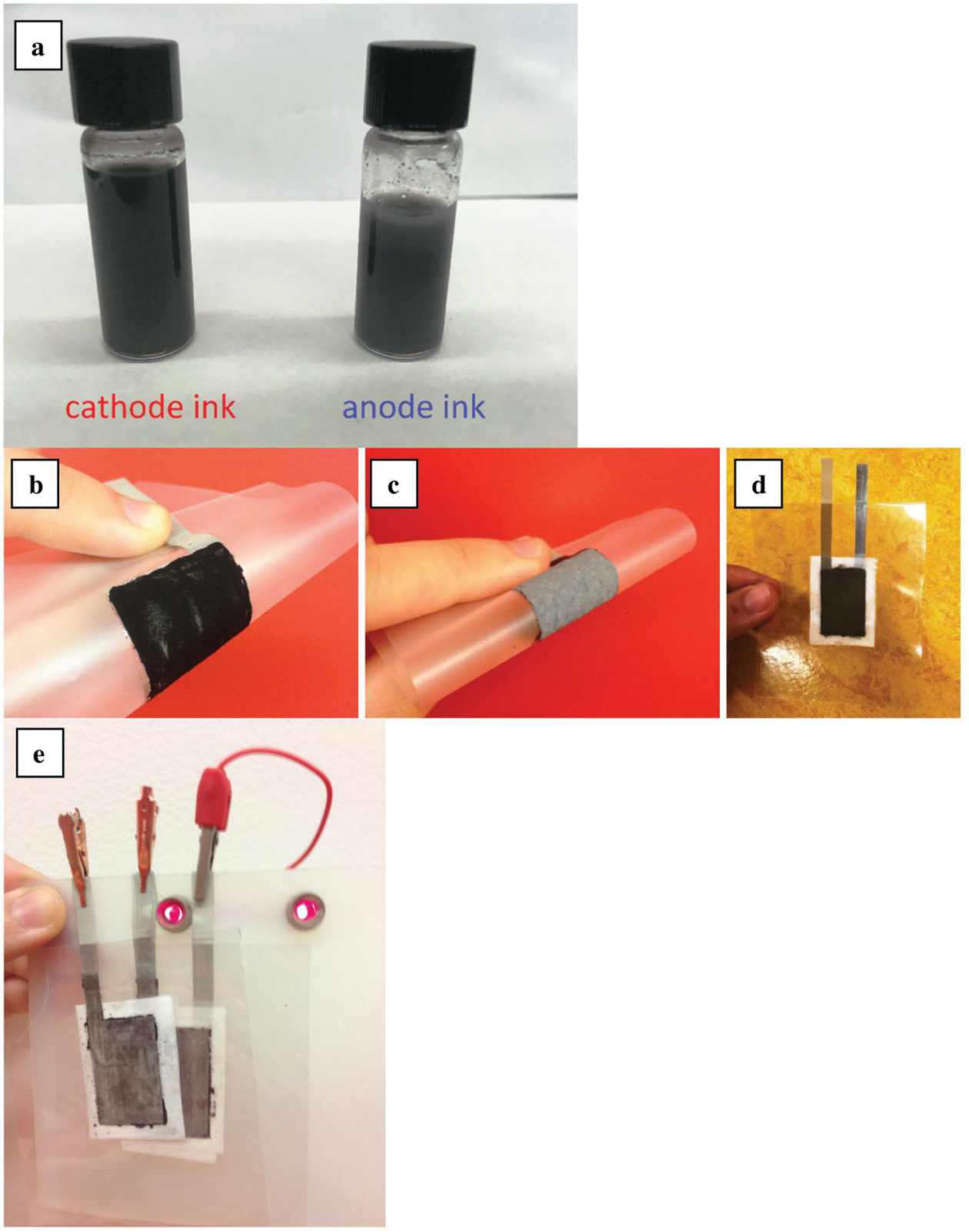

Figure 1.

a) Electrode inks from synthesized metal oxide-CNT composites; photograph of b) flexible cathode, c) flexible anode, d) an assembled cell, and e) two cells powering up LED lights. 

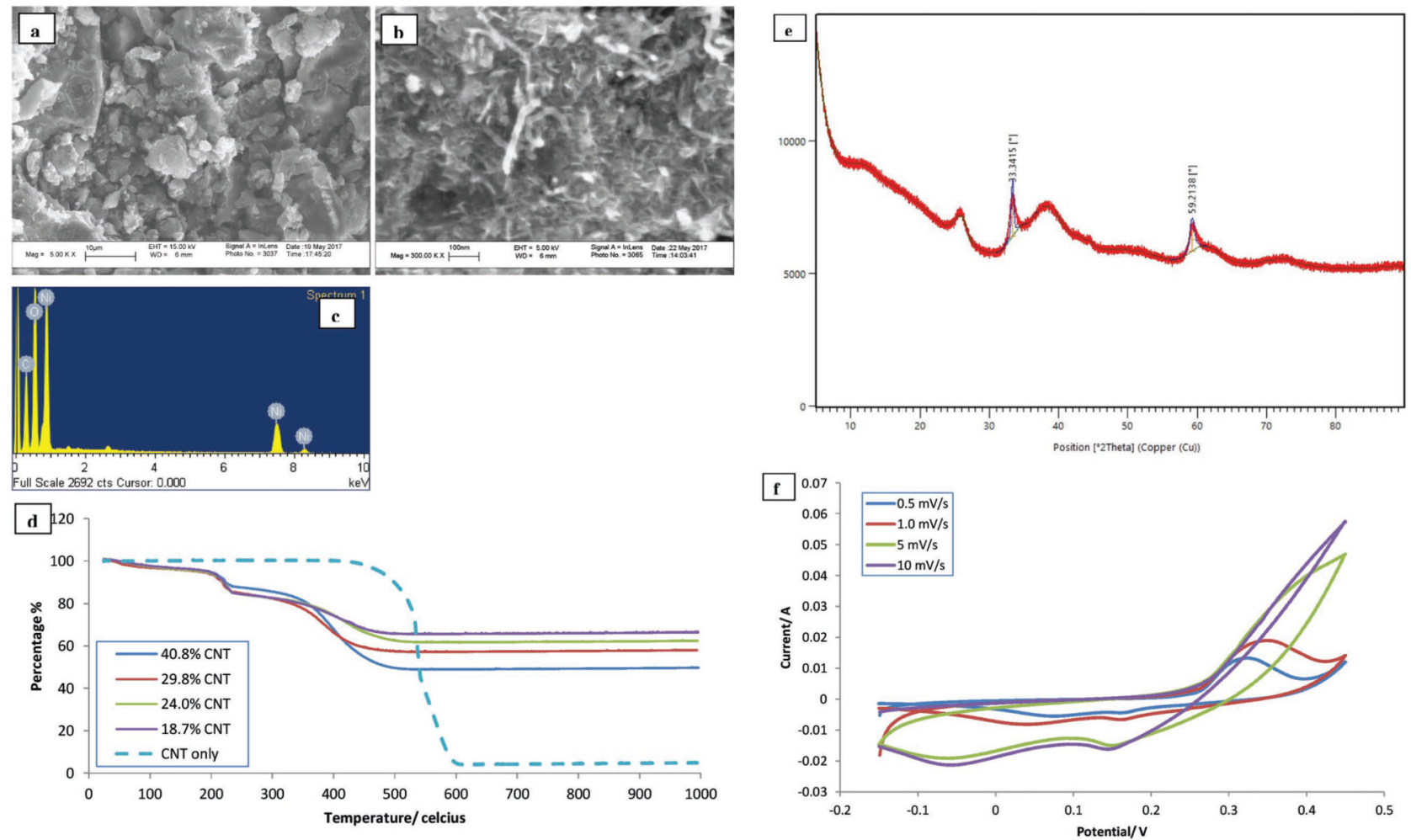

Figure 2.

a,b) SEM images of $\mathrm{Ni}(\mathrm{OH})_{2}$-CNT composites; c) EDS results showing the major elements in $\mathrm{Ni}(\mathrm{OH})_{2}$-CNT composite; d) TGA analysis of $\mathrm{Ni}(\mathrm{OH})_{2}-\mathrm{CNT}$ composites with different amounts of CNTs; e) XRD analysis of $\mathrm{Ni}(\mathrm{OH})_{2}-\mathrm{CNT}_{29.8}$ composite; f) cyclic voltammetry of composite $\mathrm{Ni}(\mathrm{OH})_{2}-\mathrm{CNT}_{29.8}$ versus $\mathrm{Ag} / \mathrm{AgCl}$ electrode. 


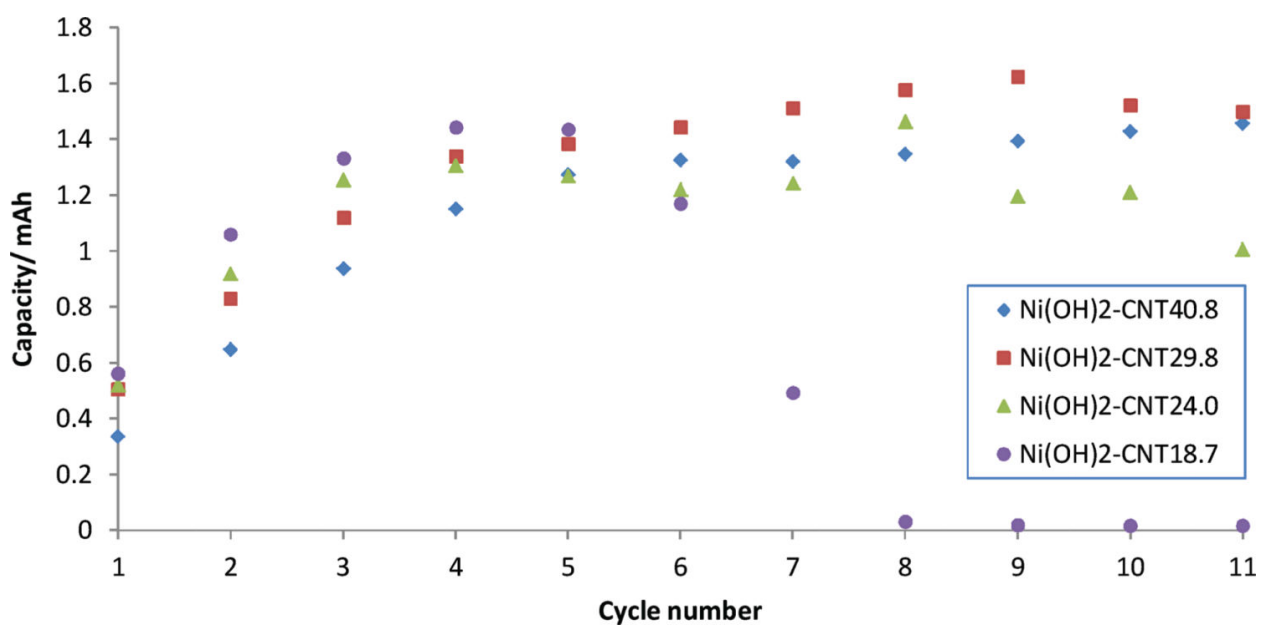

Figure 3.

Capacity as a function of cycle numbers for Swagelok cells with electrodes containing different $\mathrm{Ni}(\mathrm{OH})_{2}$-CNT composites. 

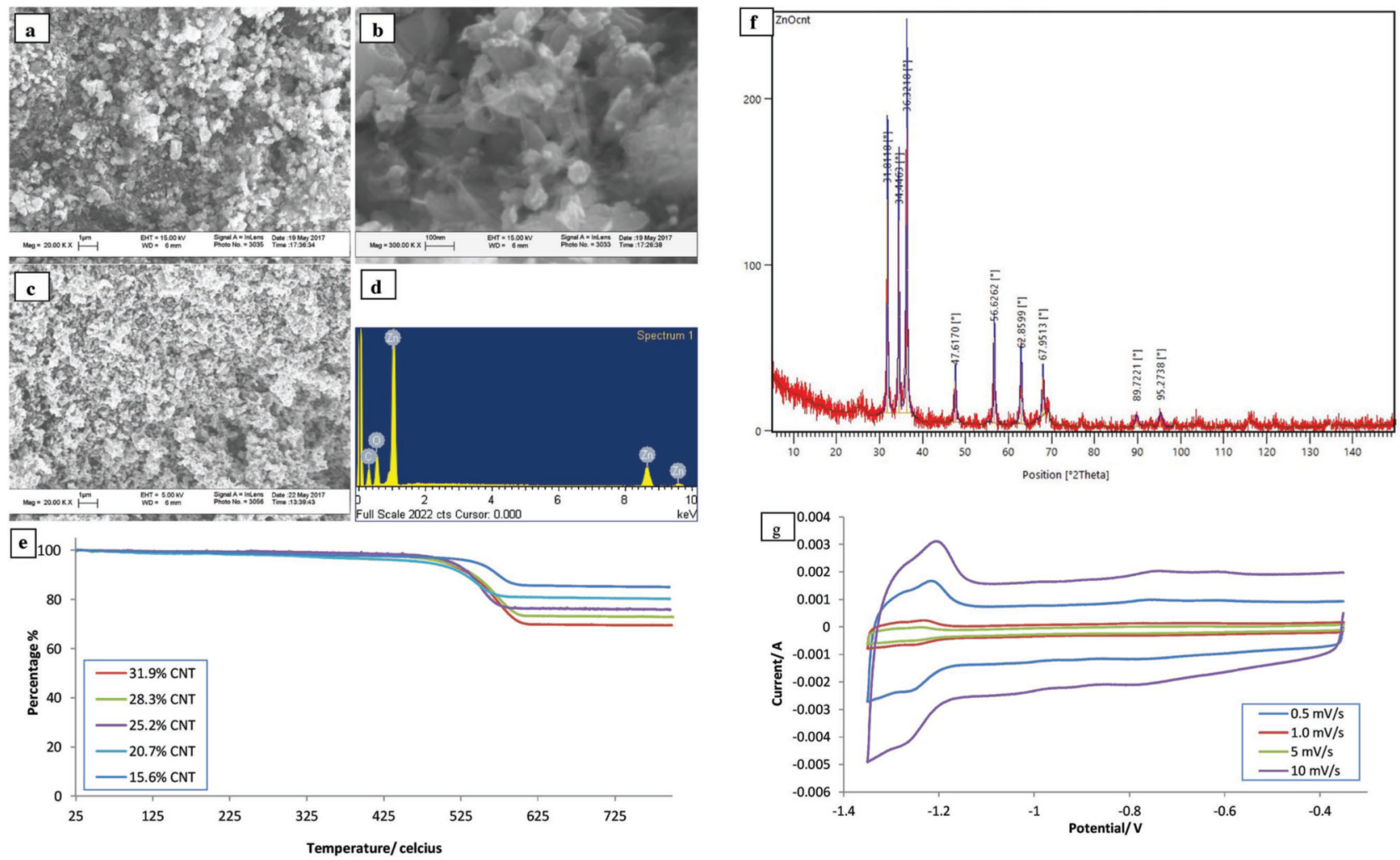

Figure 4.

a,b) SEM images of ZnO-CNT composites; c) SEM images of pure ZnO; d) EDS results showing the major elements in ZnO-CNT composite; e) TGA analysis of ZnO-CNT

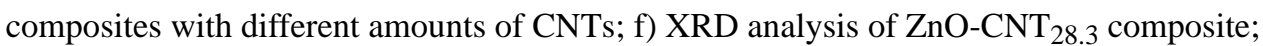
g) cyclic voltammetry of $\mathrm{ZnO}_{-} \mathrm{CNT}_{28.3}$ versus $\mathrm{Ag} / \mathrm{AgCl}$ electrode. 


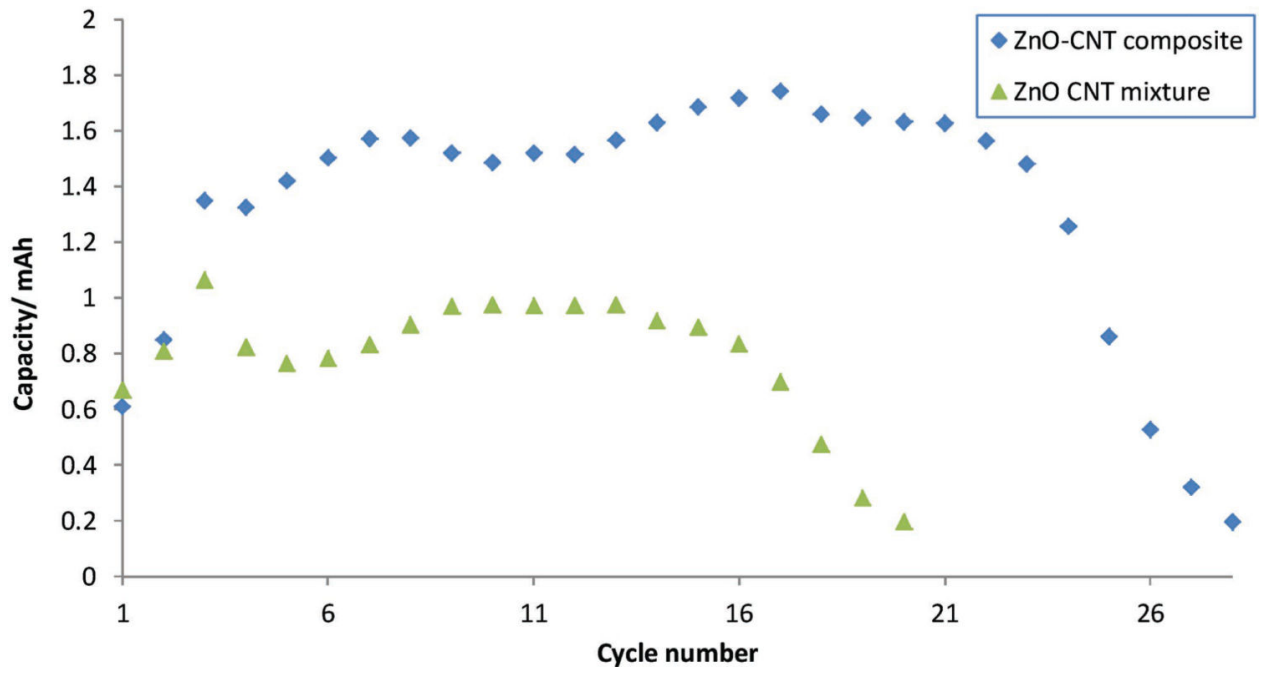

Figure 5.

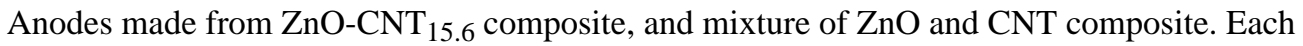
anode also contained $1 \%$ cellulose, $4 \%$ binder, $2 \% \mathrm{Bi}_{2} \mathrm{O}_{3}$, and $54 \%$ zinc metal. 

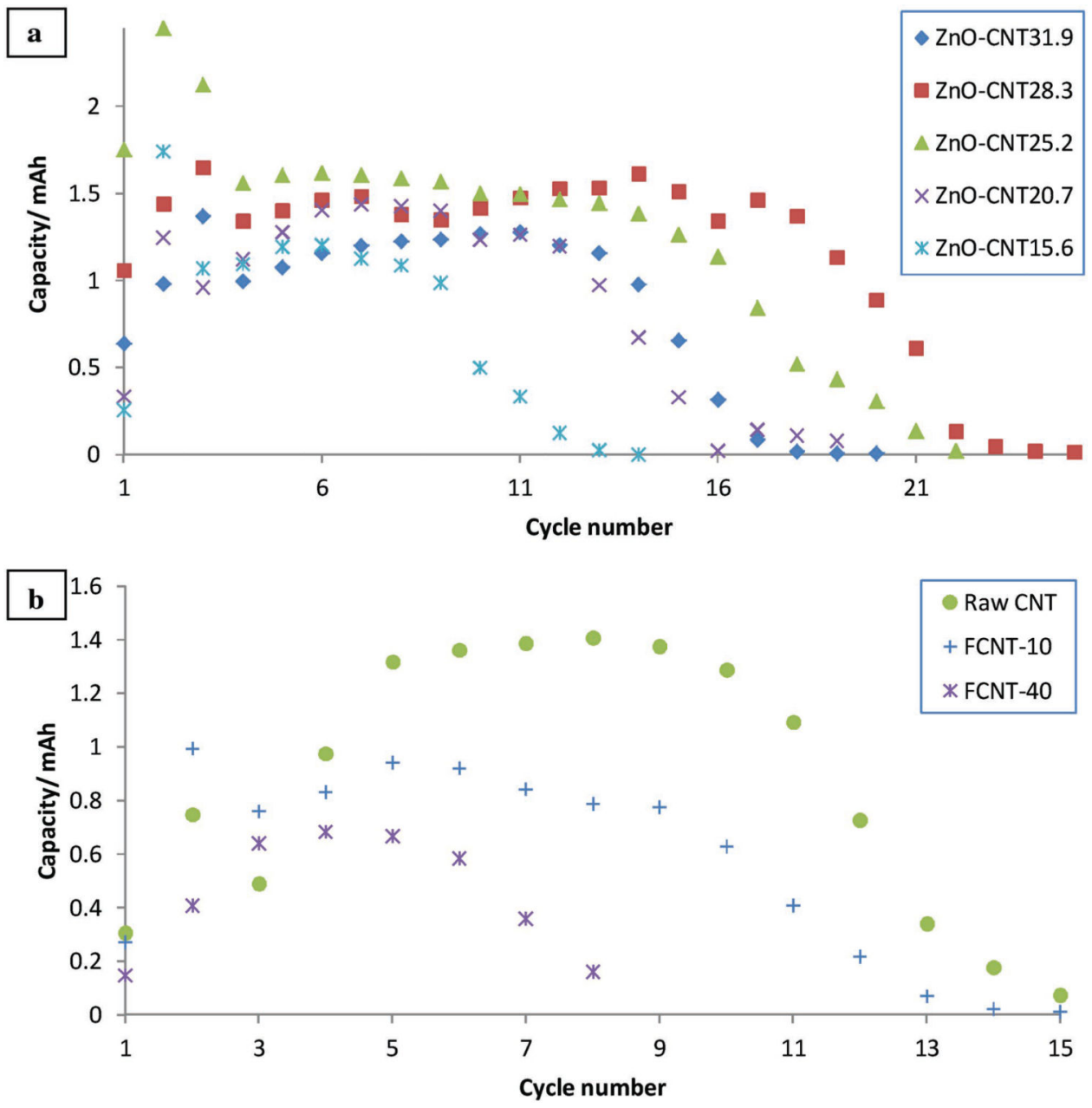

Figure 6.

Performance of $\mathrm{ZnO}-\mathrm{CNT}$ composite anodes (each anode contained $64 \%$ by weight of the ZnO-CNT composite and $22 \%$ zinc metal): a) composites containing different amounts of CNTs; b) anode with $\mathrm{ZnO}-\mathrm{CNT}_{28.3}$ composites synthesized from carboxylated CNTs. 


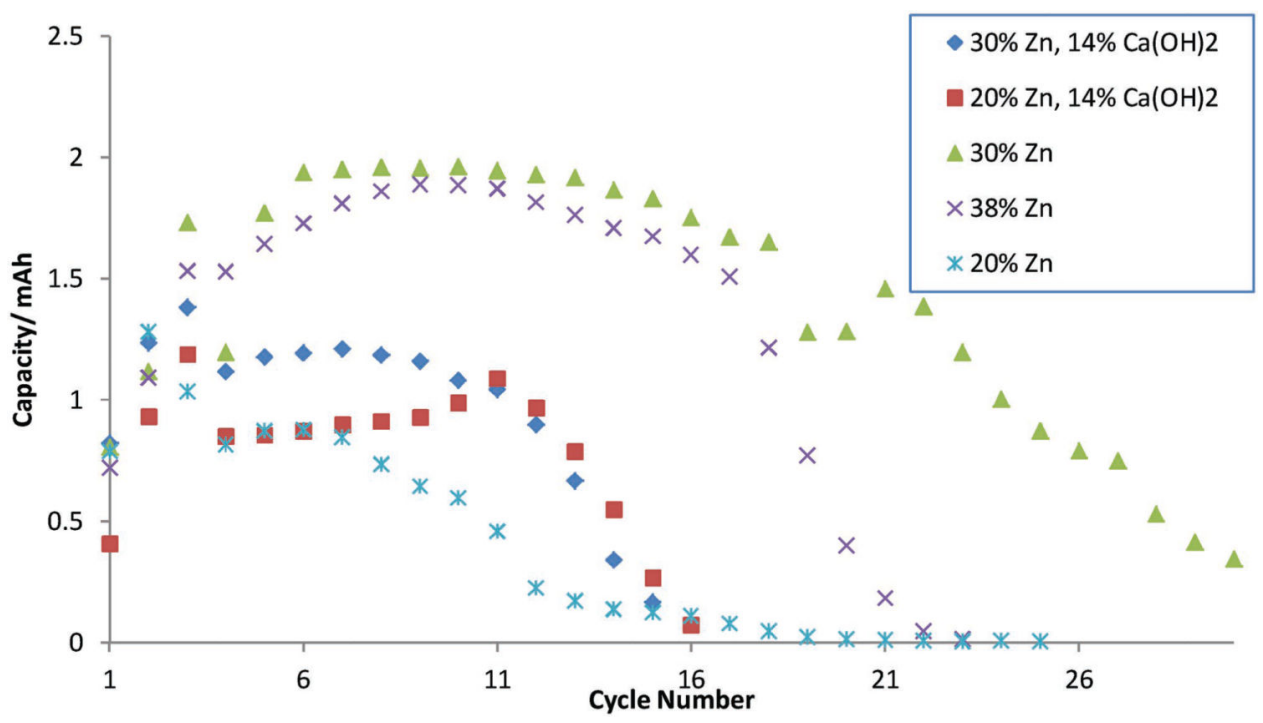

Figure 7.

Anode with and without $\mathrm{Ca}(\mathrm{OH})_{2}$, and different amount of zinc metal (all electrodes also contained $\mathrm{ZnO}-\mathrm{CNT}_{28.3}$ ). 


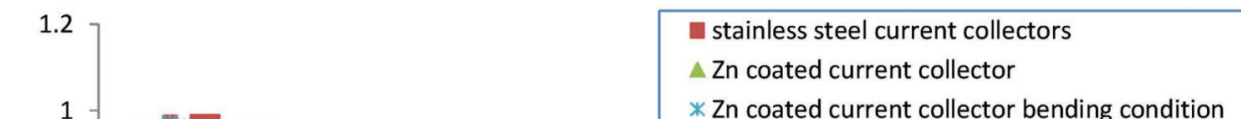

Figure 8.

Flexible Ni-Zn cells under flat and bending conditions $(r=5.5 \mathrm{~cm})$. 


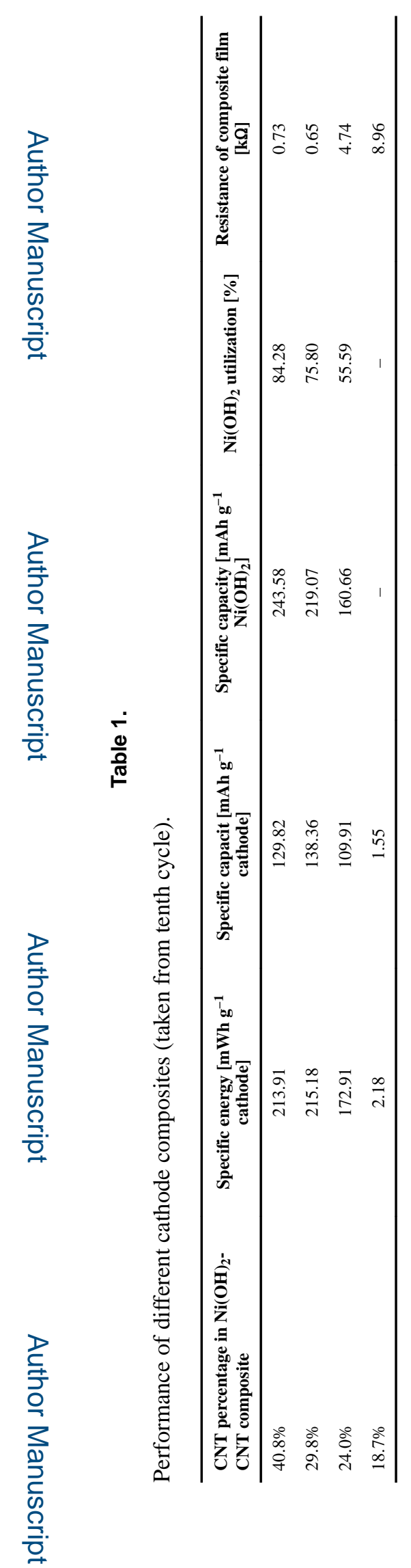

Adv Mater Interfaces. Author manuscript; available in PMC 2018 November 30. 
Table 2.

Performance of different anode composites (taken from 11th cycle).

\begin{tabular}{lccc}
\hline $\begin{array}{l}\text { CNT percentage in ZnO-CNT } \\
\text { composite }\end{array}$ & $\begin{array}{c}\text { Specific energy [mWh } \mathbf{~}^{-1} \\
\text { anode] }\end{array}$ & $\begin{array}{c}\text { Specific capacity [mAh g-1 } \\
\text { anode] }\end{array}$ & $\begin{array}{c}\text { Resistance of composite film } \\
{[\mathbf{k} \Omega]}\end{array}$ \\
\hline $31.9 \%$ & 165.00 & 99.69 & 3.7 \\
$28.3 \%$ & 189.53 & 115.31 & 1.2 \\
$25.2 \%$ & 195.78 & 116.88 & 2.4 \\
$20.7 \%$ & 165.63 & 98.60 & 34 \\
$15.6 \%$ & 44.29 & 25.94 & 75 \\
\hline
\end{tabular}


Table 3.

EDS results for CNTs.

\begin{tabular}{lccc}
\hline Element (weight \%) & Raw CNTs & FCNT-10 & FCNT-40 \\
\hline $\mathrm{C}$ & 92.67 & 87.88 & 86.34 \\
$\mathrm{O}$ & 6.10 & 11.25 & 13.55 \\
$\mathrm{Ni}$ & 1.23 & 0.87 & 0.11 \\
\hline
\end{tabular}

